\title{
Practical and Theoretical Modeling of Anaerobic Digestion of Sargassum spp. in the Mexican Caribbean
}

\author{
Héctor López-Aguilar ${ }^{1}$, Guadalupe Kennedy-Puentes², Jorge Gómez ${ }^{2}$, \\ Enrique Huerta-Reynoso ${ }^{2}$, María del Rosario Peralta-Pérez ${ }^{3}$, \\ Francisco Zavala-Díaz de la Serna ${ }^{3}$, Antonino Pérez-Hernández ${ }^{2 *}$ \\ ${ }^{1}$ Universidad La Salle de Chihuahua. Prolongación, Lomas de Majalca 11201, \\ Labor de Terrazas, 31020 Chihuahua, México \\ ${ }^{2}$ Centro de Investigación de Materiales Avanzados, Avenida Miguel de Cervantes Saavedra 120, \\ Complejo Industrial Chihuahua, 31136 Chihuahua, México \\ ${ }^{3}$ Universidad Autónoma de Chihuahua, Facultad de Ciencias Químicas, Circuito Universitario S/N, \\ Campus UACH II, 31125 Chihuahua, México
}

Received: 31 May 2020

Accepted: 21 October 2020

\begin{abstract}
The amount of sargassum seaweed washed ashore on the beaches of Africa, Brazil, Central America and the Caribbean has increased to the point where it has become a social, environmental and financial issue. This research evaluates the potential for Sargassum spp. of the Mexican Caribbean coast to be used in the production of biomethane by estimating: a) stoichiometric methane production (SMP), b) biochemical methane potential (BMP) and c) biodegradability index (BI).

The use of a sigmoidal model generalized to substrate to inoculum ratios is proposed, to predict the biomethane production during the anaerobic digestion (AD) of the sargassum. The information obtained shows the seaweed's potential for biomethane production and will be useful for estimates and scaling when implementing energy harnessing systems for sargassum in the Caribbean. The use of biomass is a key element in the move towards a circular economy. It is hoped that the use of technologies like $\mathrm{AD}$ leads to the integration of this seaweed into an economic value chain, thereby reducing the adverse effects of its presence on the ecosystem.
\end{abstract}

Keywords: BMP, biogas, biomass, sigmoidal model, biomethane

*e-mail: antonino.perez@cimav.edu.mx 


\section{Introduction}

The great Atlantic sargassum belt was identified by satellite observation, and extends from the west coast of Africa to the Gulf of Mexico. It is estimated to have a length of 8 thousand kilometers and a mass of 20 million tonnes [1]. This Phaeophyceae type floating algae can grow and move throughout the Caribbean. The sargassum's abundance and mobility are related to complex surface transport processes, and so the sargassum that enters the Caribbean may not exclusively originate from the east of the Equatorial Atlantic and some could be entering from other regions [2].

The Caribbean is one of the most important international tourist regions. Its biodiversity, as well as its existing tourist infrastructure, generate a large part of the local financial income. The mass arrival of Sargassum spp. to the beaches is an issue that currently lacks information regarding trends, blooms, ecological and biochemical impacts, as well as feasible options for its disposal [1, 3-5]. Proposals for proper disposal have been expensive and with little success [6, 7]. The Caribbean Regional Fisheries Mechanism (CRFM) estimated a cleaning cost for the sargassum of \$ 210 million dollars in 2018 [8].

The seaweed washed ashore has increased so much that it has become an issue of social, environmental and financial nature in the affected regions [4, 7-9]. One of the impacts of this unlikely visitor to the Mexican Caribbean coast since 2015, is the generation of coastal areas known as sargassum brown tides. This phenomenon has caused an increase in the organic material load and water turbidity, thereby damaging the coastal ecosystem [10]. It is estimated that along the Mexican Caribbean coast alone, 78 species are affected, which are mainly fish with demersal neritic habitats and other fauna like sea cucumbers, crabs and octopus, given the hypoxic conditions, high concentrations of hydrogen sulphide and ammonium, leading to a deterioration in the water quality [7]. Furthermore, navigation is limited as the sargassum attaches to the rotary blades of boats and fishing vessels causing damage to motors [11].

Sargassum spp. has been identified as a type of seaweed that is one of the major natural sources of bioactive compounds [12]. The polysaccharides of the sargassum mainly consist of: fucoidan, alginic acid, luminaran and insoluble fiber, the first of which displays pharmacological properties, such as being an antioxidant and strengthening the immune system [13, 14]. Jesumani et al. found, using in vitro experiments, that the sulfated polysaccharides extracted from the algae: Sargassum vachellianum, Sargassum horneri, and Sargassum hemiphyllum display strong antioxidant activity, inhibition of tyrosinase and elastase, as well as the ability to absorb and retain humidity showing promisingly strong potential as a cosmetics ingredient [15]. Fernández et al. [16] confirm that the use of Sargassum S. fluitans and Sargassum natans, without any other treatment in animal feed or as an agricultural fertilizer, could incorporate toxic metals into the food chain and increase the salt concentration of the soil.

Several diverse studies have found the anaerobic digestion (AD) of Sargassum spp. feasible for the production of third generation biofuels [9, 17-19]. However, the presence of multiple recalcitrant components such as sulphates, sodium chloride and heavy metals in significant concentrations could accumulate and act as inhibitors of the $\mathrm{AD}[20,21]$. Thompson et al. [22] indicate that the presence of heavy metals remains in the digestate after the $\mathrm{AD}$, contaminating and limiting the use of this subproduct as an organic soil improver. Its application could lead to inducing the acidification of the soil and toxicity of vegetable species. Furthermore, it was discovered that elements such as $\mathrm{Fe}, \mathrm{Ni}, \mathrm{Co}, \mathrm{Mb}, \mathrm{Zn}, \mathrm{Ca}, \mathrm{Cu}$ and $\mathrm{Ba}$ are essential micronutrients for $\mathrm{AD}$, as they act as cofactors in the active sites of the enzymes [23-25]. Therefore, it is important to carry out studies that enable us to identify the potential of AD in the disposal of sargassum and facilitate its implementation for the energetic harnessing of this biomass.

The purpose of this study is to carry out the practicaltheoretical modeling of the AD of the sargassum reaching the Mexican Caribbean coastline, and its conversion to biogas, by defining the main parameters of this biomass. The aim is, that the information obtained will promote the use of this seaweed as part of an economic value chain and help reduce the adverse effects of its presence on the ecosystem.

\section{Experimental}

\section{Biomass Sampling and Characterization}

The Mexican Caribbean is located in the Mexican state of Quintana Roo, consisting of beaches such as Puerto Morelos, Playa del Carmen, Cozumel, Akumal, Tulum, Isla Mujeres, Bacalar, amongst many others [26]. Some studies have identified the seaweed washed ashore on these coasts as Sargassum fluitans (Børgesen) Børgesen y $S$. natans (Linnaeus) Gaillon [5, 27]. For the purpose of the experiment, samples of Sargassum spp. seaweed washed ashore at the hotel area of Cancun $\left(21^{\circ} 4^{\prime} 04.1^{\prime \prime} \mathrm{N}, 86^{\circ} 46^{\prime} 33^{\prime \prime} \mathrm{W}\right)$ were taken during the month of June 2019. A total of $10 \mathrm{~kg}$ of fresh sargassum was collected and the sampling was made at the seashore of the coastal area. The biomass was washed in plain water and dried in the sun for four days at normal environmental temperature. Lastly, it was stored for its characterization, in high-density polyethylene bags under normal environmental conditions.

The elements $\mathrm{C}, \mathrm{H}, \mathrm{O}, \mathrm{N}$ present in the samples or analysis were determined via element chromatography using Thermoscientific Flash Smart equipment with Porapak PQS column and molecular sieve, using helium as a carrier gas. 
Volatile solids (VS) of the sargassum and inoculum were determined under the Standard Method 2540 E [28], using a Shel Lab forced air oven and Thermolyne 48000 muffle furnace. The percentage humidity and ashes were determined via thermogravimetric analysis [29], using STA 2500 Regulus equipment with a temperature ramp of $10 \mathrm{~K} / \mathrm{min}$.

The gross caloric value of the sargassum was calculated with three repetitions, using a Parr 6400 calorimeter. The released volatile compounds were identified from the TG-GC-MS coupled analysis, during the thermal treatment of the pyrolysis. The equipment used in this coupled analysis was: Agilent 7890B gas chromatograph and 5977B (GC/MS) mass spectrometer coupled to the STA 2500 Regulus via a JAS transfer line. Helium $(99.999 \%)$ was used as a carrier gas at a flow rate of $210 \mathrm{ml} / \mathrm{min}$, in a Porapak 19091S-433UI column of 30 meters coupled to a simple MS quadrupole using a mass range of 35 to $450 \mathrm{~m} / \mathrm{z}$ to characterize the volatiles emitted during the thermal treatment of the sargassum. 15 injections were carried out at a constant temperature of $150^{\circ} \mathrm{C}$ in the entire system, for each of the 4 characterizations.

Identification of the presence of metals and metalloids in the sargassum collected and digestate produced in the $\mathrm{AD}$ experimentation was carried out according to the NMX-AA-051-SCFI [30] methodology. Two digital hot plates were used with Corning Pyroceram PC-260D agitation and a GBC AVANTA atomic absorption spectrophotometer.

\section{Models to Estimate Biomethane Production}

In practice, different stoichiometric models were used to estimate the biomethane generation from the anaerobic fermentation of the biomass, the majority of which require a large number of input parameters, with Buswell being one of the most well-known models. Based on the elemental chemical composition obtained using chromatography, the stoichiometric methane production (SMP) of the digesters was estimated using the Buswell equation [31] (Eq 1).
Eq. (1) Buswell equation

$$
\begin{gathered}
C_{n} H_{a} O_{b}+\left(n-\frac{a}{4}-\frac{b}{2}\right) H_{2} O \rightarrow\left(\frac{n}{2}+\frac{a}{8}-\frac{b}{4}\right) C_{4}+ \\
\left(\frac{n}{2}-\frac{a}{8}+\frac{b}{4}\right) \mathrm{CO}_{2}
\end{gathered}
$$

The biochemical methane potential (BMP) test is an experimental test to estimate the maximum methane production and digestibility of diverse organic substrates. To estimate the BMP it is essential to characterize the volatile solids (VS) given that the test results are presented in $\mathrm{cm}^{3}$ of $\mathrm{CH}_{4} / \mathrm{g}$ VS.

The AD was carried out in batch digesters in $0.25 \mathrm{~L}$ bottles of HDPE Nalgene, sealed with a lid/septa of PTFE/silicone 0.135 inches in thickness. The anaerobic fermentation of the sargassum was carried out according to BMP methodology [32]. The inoculum was anaerobic activated sludge, obtained from a wastewater treatment plant in the south of the city of Chihuahua, Mexico. The inoculum was preserved in a $10 \mathrm{~L}$ container at $4^{\circ} \mathrm{C}$ until use. The substrate used was the sargassum dried at $103^{\circ} \mathrm{C}$ in an oven for 2 hours and then crushed and homogenized to be loaded to the digesters identified as: D1, D2, D3, D4, the characteristics of each digester can be seen in Table 1. D1 was considered the baseline to identify the inoculum's biogas generation potential. Subsequently, all experiments were subject to the extraction of the air present inside the reactor with a chromatographic syringe to minimize the presence of oxygen. The reactors were maintained at a temperature of $37 \pm 5^{\circ} \mathrm{C}$ in a VWR Scientific Products 1545 incubator for 38 days. The AD tests were carried out in triplicate and the results presented are an average of these. The biogas was monitored every three days, measuring: a) volume of biogas generated, extracting it using a chromatographic $50 \mathrm{~mL}$ syringe, b) composition of the biogas was analyzed using a Micro GC INFICON gas chromatography in which the $\mathrm{CO}_{2}, \mathrm{CH}_{4}$ and $\mathrm{H}_{2} \mathrm{~S}$ gases were quantified.

The BMP experimental curves were plotted using the generated experimental values.

Table 1. Experimental parameters of the digesters: D1, D2, D3, D4.

\begin{tabular}{|c|c|c|c|c|}
\hline Parameter & Unity & D2 & D3 & D4 \\
\hline Inoculum, Substratum & $\mathrm{mL}, \mathrm{g}$ & 150,10 & 150,20 & 150,30 \\
\hline $\mathrm{CH}_{4}$ volume produced (BMP) & $\mathrm{cm}^{3} / \mathrm{g} \mathrm{SV}$ & 348 & 319 & 183 \\
\hline Sargassum SV in the DA system & $\mathrm{g}$ & 2.575 & 5.15 & 7.725 \\
\hline Theoretical volume $\mathrm{CH}_{4}(\mathrm{SMP})$ & $\mathrm{cm}^{3} / \mathrm{g} \mathrm{SV}$ & 839.65 & 1617.3 & 2394.95 \\
\hline S:I ratio & ---- & $1.4: 1$ & $2.7: 1$ & $4.1: 1$ \\
\hline Performance $=$ BMP/SMP & ---- & 41.44 & 19.72 & 7.64 \\
\hline Biodegradability Index (BI) & $\%$ & 58.55 & 80.27 & 92.35 \\
\hline
\end{tabular}


CurveExper Professional 2.6.5. software was used to predict the behavior in the experimental systems D2, D3 and D4,

The biodegradability index (BI), Eq. (2), was used to estimate the efficiency of the digestion via BMP tests and using the estimated SMP values [33].

Eq. (2) biodegradability index

$$
\mathrm{BI}=\mathrm{SMP}-\mathrm{BMP} / \mathrm{SMP}
$$

\section{Results and Discussion}

\section{Sargassum Characterization}

The Sargassum spp. is a brown seaweed distributed around the world's tropical oceans [11]. Due to its arrival in abundance to the Caribbean coast in recent years, its suitable treatment has been investigated. AD could be a viable option that should be evaluated.

The ultimate analysis of the sargassum sample from the Mexican Caribbean was 28.8\% C, 3.4\% $\mathrm{H}$, $1.2 \% \mathrm{~N}$ and $39.7 \% \mathrm{O}$. Based on this elemental analysis carried out a chemical formula was determined for the sargassum $\mathrm{C}_{27} \mathrm{H}_{39} \mathrm{O}_{29} \mathrm{~N}$. In the inoculum sample of the water treatment plant $35.1 \% \mathrm{C}, 5.7 \% \mathrm{H}, 4.1 \% \mathrm{~N}$ and $22.3 \% \mathrm{O}$ was found.

The recommended range of the Carbon-Nitrogen $(\mathrm{C} / \mathrm{N})$ ratio of the raw materials for biogas production is between $16 / 1$ and $45 / 1$ for the efficient performance of the digester without inhibiting the process [31]. When

Table 2. GC-MS results detected in the volatiles of the pyrolysis.

\begin{tabular}{|c|c|}
\hline Substance & $\begin{array}{c}\text { Number of times it } \\
\text { was detected }\end{array}$ \\
\hline phenylmethyl N-aminocarbamate & 4 \\
\hline $\begin{array}{c}\text { Benzaldehyde, 3-benzyloxy-2-fluoro- } \\
\text { 4-methoxy }\end{array}$ & 3 \\
\hline Phenyl N-methylcarbamate & 3 \\
\hline (1-ethynylcyclohexyl) carbamate & 3 \\
\hline Byciclo hexan-2-ol, 2 ethenyl & 3 \\
\hline $\begin{array}{c}\text { Butanedioic acid, 2-cyano-2,3-dime- } \\
\text { thyl, diethyl ester }\end{array}$ & 3 \\
\hline (1S,2R)-Cyclopent-3-ene-1,2-diol & 2 \\
\hline 1-methylpyrazole-4-carbaldehyde & 2 \\
\hline 2-Acetylfuran & 2 \\
\hline [(E)-tetradec-9-enyl] acetate & 2 \\
\hline Bicyclo[2.2.1]hept-2-en-7-ol & 2 \\
\hline (3E)-3-prop-2-enylidenecyclobutene & 2 \\
\hline 2-pentadecyn-1-ol & 2 \\
\hline 2-Hexyldecan-1-ol & 2 \\
\hline
\end{tabular}

this ratio is very high, nitrogen consumption happens quickly and biogas production decreases, whereas when the ratio is less than 15 inhibitors may accumulate, such as ammonia and volatile fatty acids [34]. Furthermore, it was discovered that out-of-range values like the 50/1 ratio were suitable for AD [21]. Filer et al. [35], identified that a $\mathrm{C} / \mathrm{N}$ ratio of $40 / 1$ leads to optimal operation of the digesters. Marquez et al. [17] reported very variable $\mathrm{C} / \mathrm{N}$ ratios in marine algae biomasses that ranged from 8.72 to 58 . This investigation determined a $\mathrm{C} / \mathrm{N}$ ratio of 27 and estimated a theoretical production of methane in the range of 839.65 to $2394.95 \mathrm{~cm}^{3}$ of $\mathrm{CH}_{4} / \mathrm{g} \mathrm{VS}$ for the total anaerobic degradation of Mexican Caribbean sargassum.

It has been reported that the biomasses display a range of volatile solids from 9.96 to $93 \%$ [36]. In this work, values of $27.75 \%$ and $12.43 \%$ for the sargassum and sludge were determined respectively, adhering to international standards. Fig. 1 displays thermograms for the 4 samples of sargassum from the Mexican Caribbean.

By means of the thermogravimetric analysis of the sargassum, it was determined that the average humidity loss was $3.38 \%$, during the first $115^{\circ} \mathrm{C}$ with a standard deviation of 1.23 , and this value is associated with the drying technique used for the samples. The amount of volatiles present in the sample was identified in the range of 115 to $550^{\circ} \mathrm{C}$, with a standard deviation of 2.68 , and in this region of the thermal curve the hemicellulose and cellulose are thermally degraded. From $550^{\circ} \mathrm{C}$ the sample's weight loss is associated with the lignin present in the biomass. Lastly, reaching $825^{\circ} \mathrm{C}$ the change in weight is related to the de-carbonation of the $\mathrm{CaCO}_{3}$ releasing $\mathrm{CO}_{2}$, for which the remaining ash, the $26.52 \%$ of the analyzed sample will be material rich in $\mathrm{CaO}$ and with the presence of metals.

Using TG-GC-MS analysis, the main volatiles released during the samples' pyrolysis were identified, a process that represents the first part of the combustion of solid particles. What was mainly detected were aromatic compounds, as well as nitrogenous, aldehyde, ketone, ester and aldehydes and carboxylic acid compounds. Table 2 shows the volatile compounds that were detected in at least 2 of the 4 TG-GC-MS analyses.

All of the compounds presented in Table 2 (except for the carbamates) agree with those detected by Vilar et al. [37] in the algae Laminaria spp. Studies report some of these compounds as toxic. The pesticide carbamates (CBM's) for example, are compounds extensively used in agriculture and whose improper use have generated environmental issues. Organizations such as USEPA and the European Union have cataloged these kinds of compounds as potentially toxic and limited their use as a fertilizer [38]. It was also found that the sensitivity of some algae species, exposed to CBM's, varies from one to two orders of magnitude [39].

The sargassum presented an average calorific value of 9.69 megajoules per kilogram with a standard deviation of 0.17 . However, this is a low value compared 


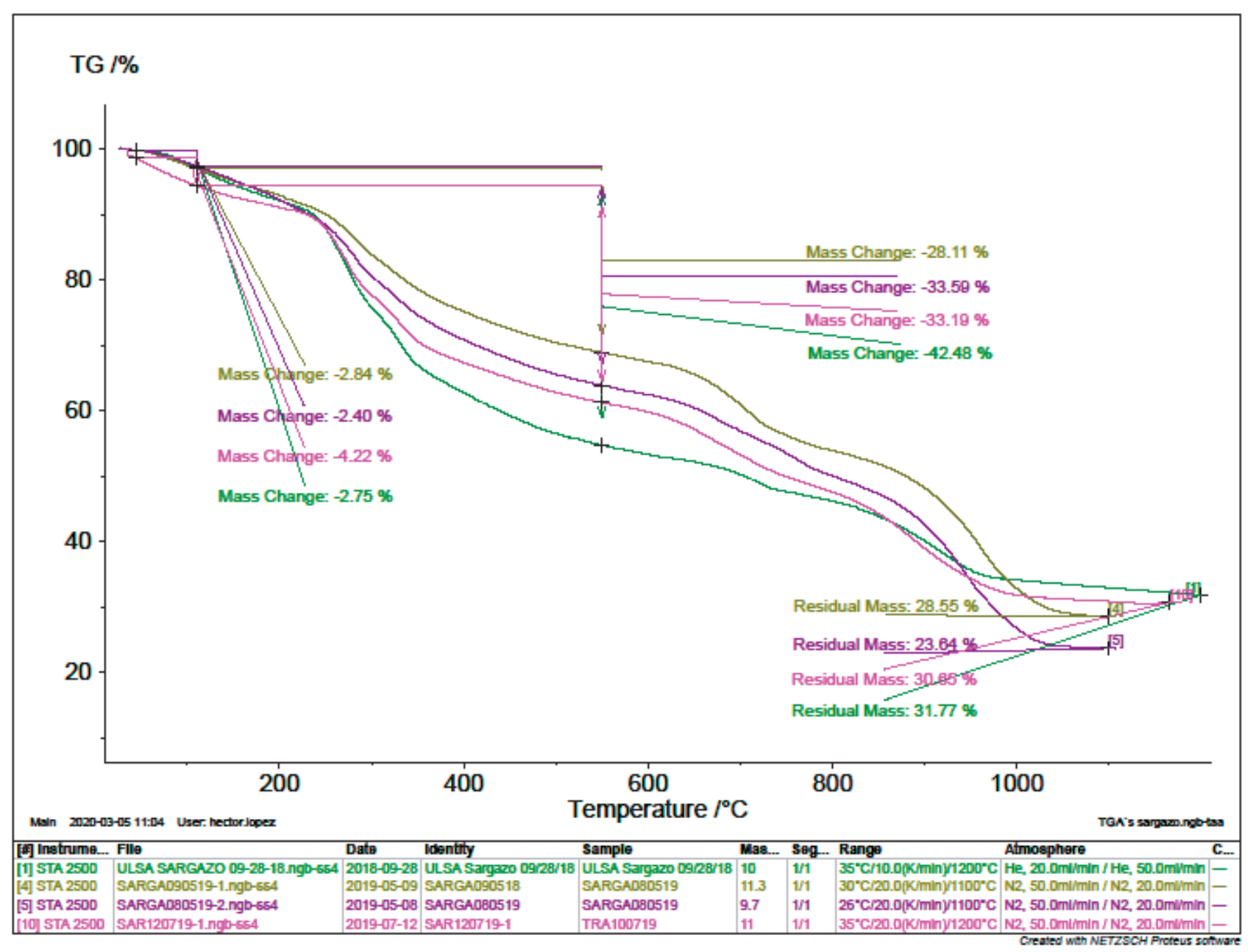

Fig. 1. Sargassum TGA and values obtained from the biomass ultimate analysis.

to the $21.5,15.77$ and 13.16 megajoules per kilogram determined by the authors for this paper in samples of residual sawdust, sludge from wastewater treatment plants and livestock manure, respectively.

Table 3 shows metals and metalloids detected in the sargassum and digestate samples used in the experiments. The concentrations of $\mathrm{Al}, \mathrm{Ba}, \mathrm{Cr}, \mathrm{Cu}$, $\mathrm{Mg}, \mathrm{Mn}$ and $\mathrm{Zn}$ present in the sargassum are associated with its ability to behave as a bio-absorbent matrix. In this manner, its potential for use in the capture of contaminants in coastal ecosystems was identified [11]. According to Thompson et al. [22], the presence of heavy metals was detected in the digestate after the $\mathrm{AD}$, mainly $\mathrm{Ca}, \mathrm{Mg}, \mathrm{Al}$ and $\mathrm{Fe}$.

In all cases, the concentrations of metals and metalloids detected in the samples were not considered hazardous for the ecosystem according to the standard NOM-001-SEMARNAT [40], which sets out the maximum admissible limits for contaminants in waste water discharged to watercourses and soils in Mexico. It was shown that the presence of the elements in Table 3 was favorable for AD. According to Ganesh Saratale et al. [23] these elements can act like micronutrients. And in some cases as enzyme cofactors, especially the microelements: $\mathrm{Fe}, \mathrm{Ni}$ and $\mathrm{Mo}$ can balance out the availability of nutrients for anaerobic microorganisms [25].

\section{Estimate of Biomethane Production}

When monitoring biogas production in the experimental digesters under the described conditions (Table 1), the production of biogas was observed from the very first day. An increase in the methane content was observed from day 6 , which remained constant until day 35 , and this behavior was observed in all cases. The experimental systems D2, D3 and D4 displayed greater methane production in comparison to the baseline D1, which shows the potential for methane production and the importance of the inoculum using the sargassum as raw material for the $\mathrm{AD}$.

According to Nkemka \& Murto [20] the retention time required for the anaerobic fermentation of the marine biomass is 14 days. This investigation identified a required retention time of at least 35 days for the anaerobic degradation of the sargassum under mesophilic conditions $\left(37 \pm 5^{\circ} \mathrm{C}\right)$. The digester D2 displayed greater production than the others, 
Table 3. Identification of metals and metalloids present in sargassum samples in mg/liter (ppm).

\begin{tabular}{|c|c|c|c|c|c|c|c|c|c|}
\hline Sample & $\mathrm{Al}$ & $\mathrm{Ba}$ & $\mathrm{Ca}$ & $\mathrm{Cr}$ & $\mathrm{Cu}$ & $\mathrm{Fe}$ & $\mathrm{Mg}$ & $\mathrm{Mn}$ & $\mathrm{Zn}$ \\
\hline Beach sargassum & 0.032 & 0.243 & 539.500 & 0.011 & 0.036 & 0.251 & 75.267 & 0.156 & 0.098 \\
\hline Digestate D2 & 1.180 & 0.061 & 43.195 & 0.017 & 0.059 & 0.926 & 7.881 & 0.040 & 0.225 \\
\hline Digestate D3 & 1.286 & 0.073 & 61.623 & 0.020 & 0.071 & 0.922 & 12.580 & 0.049 & 0.253 \\
\hline Digestate D4 & 1.964 & 0.107 & 135.056 & 0.043 & 0.103 & 1.432 & 18.389 & 0.077 & 0.355 \\
\hline
\end{tabular}

related to an improvement in the balance between the aqueous phase and the biomass, which provided greater dissolution of the organic material.

Table 1 shows the theoretical volume of methane produced, calculated using the Buswell model and considering the sargassum's mass of VS. In order to evaluate the performance of the AD systems when compared to the calculated theoretical value, the amount of methane generated in the digesters by the inoculum was subtracted [41]. Table 1 shows the volume of methane generated in each of the experimental digesters.

Furthermore, Table 1 shows the substrate inoculum ratio (S:I) of VS for each experiment and other theoretical-practical values such as performance and the biodegradability index of the AD systems.

Moset et al. [36] in the laboratory, determined BMP values for cellulose biomasses such as maize silage, wheat straw and livestock manure to be in the range of $333.9,283.8,246.3$ and $210.9 \mathrm{~cm}^{3}$ of $\mathrm{CH}_{4} / \mathrm{g}$ VS, respectively. Lakota et al. [42] obtained average biogas production values from 384 to $635 \mathrm{~cm}^{3} / \mathrm{g}$ VS, using pig slurry and a mixture of crops in codigestion, in an experimental reactor with a capacity of 2.5 cubic meters. In their investigation, they developed linear models based on multiple regression to predict biogas production, and discovered that parameters of the biomass's composition including protein content, $\mathrm{C} / \mathrm{N}$ ratio, volatile fatty acids and $\mathrm{pH}$ value were the most significant predictors affecting biogas production.

Diverse experimental studies have determined that marine algae show values in the range of 120 to $280 \mathrm{~cm}^{3}$ of $\mathrm{CH}_{4} / \mathrm{g}$ of VS $[17,20,23]$ and similarly it was discovered that some marine algae can manage to produce $523 \mathrm{~cm}^{3}$ of $\mathrm{CH}_{4}$ with acclimatized inoculum and in co-digestion with other biomasses [33]. Specifically, in the Sargassum species, values in the range of 120 to $190 \mathrm{~cm}^{3}$ of $\mathrm{CH}_{4} / \mathrm{g}$ VS have been reached and in the waste after the extraction of the biocompounds of $107 \mathrm{~cm}$ to $405 \mathrm{~cm}^{3}$ of $\mathrm{CH}_{4} / \mathrm{g}$ VS [22, 33]. This experimental work on the $\mathrm{AD}$ of sargassum showed a production of 183 to $348 \mathrm{~cm}^{3}$ of $\mathrm{CH}_{4} / \mathrm{g}$ of VS. Variation in the literature values were mainly associated with the difference in nutrients between the substrates and the amount of inoculum used, as well as other important factors in the AD. It was discovered that the presence of nutrients is affected by seasonal changes in the seaweed's composition which has a direct impact on determining its methane potential [33].

Performances of 35 to $40 \%$ have been found in other marine algae varieties [17], and the experimental systems showed performances of between 7.6 and $41.44 \%$. According to the results of Tedesco et al. [20] and Nkemka \& Murto [33] greater performance was observed with the smallest S:I ratio of $g$ VS/ $g$ VS. This investigation found the best performance was with an S:I of 1.4:1, in digester D2, using wastewater treatment sludge as the inoculum. Li et al. [43] discovered that the highest methane production was using tomato waste with cow manure, and was obtained in reactors inoculated at a ratio of S:I 2:1 with activated sludge. Nkemka \& Murto [20] found the best marine algae AD performance with an S:I ratio of 1:2 using wastewater treatment plant sludge. The results found support the work of Moset et al. [36], that concludes that the impact of the S:I ratio, in the range of 0.4 to 4 , for different substrates depends on the type of substrate.

The digestion of sargassum under the experimental conditions of D2, D3 and D4, showed BI's of 0.58 to 0.92. The results coincide with other studies that found that the algae species Phaeophyceae shows seasonal BI rates between 0.44 and 0.9 in codigestion and with acclimatized inoculum $[33,44]$.

Furthermore, average values of 12011, 9762 and 6984 ppm of $\mathrm{H}_{2} \mathrm{~S}$ were detected in the biogas for experiments D2, D3 and D4, respectively. The variation in the concentrations detected is associated with the AD performance in each case. Sun et al. [45] report $4000 \mathrm{ppm}$ in the composition of the AD's biogas. Nkemka \& Murto [20] determined that diluted concentrations of $\mathrm{H}_{2} \mathrm{~S}$ of 300 a $500 \mathrm{ppm}$ do not interfere with the anaerobic degradation of marine algae in 20 liter reactors.

$\mathrm{H}_{2} \mathrm{~S}$ is a toxic gas and highly hazardous in trace concentrations, so it is necessary to remove it from the gas mixture. Biogas filtering will enable the $\mathrm{H}_{2} \mathrm{~S}$ to be removed from the process and prevent corrosive damage to the biogas energy harnessing systems.

In general, $\mathrm{H}_{2} \mathrm{~S}$ removal technologies can be classified as: absorption, adsorption, conversion and catalytic membrane reactor, and biological process. The technology selected must satisfy the use requirements for biogas [46]. The application of sulfur carrions as metal oxides and metal carbonates, among others, is a widely adopted practice in the petrol and gas industry [45]. 


\section{Mathematical Modeling of Biomethane Generation}

Sigmoidal behavior was identified based on the experimental data from the biomethane production, and so an adjustment was made to a sigmoidal model: Logístico and Ratkowsky. Both mathematical expressions, Logistic and Ratkowsky, express the solution of the differential equation that expresses that the gas production $\mathrm{dy} / \mathrm{dt}$ is proportional to the amount of gas generated " $y$ " and the amount of gas the system may potentially generate (a-y):

$$
\frac{d y}{d t}=k y(a-y) \quad \text { tal que } y(0)=y_{0}
$$

...where " $\mathrm{y}(\mathrm{t})$ " is the amount of $\mathrm{CH}_{4}\left[\mathrm{~cm}^{3} \mathrm{CH}_{4} / \mathrm{g}\right.$ VS] accumulated in time $\mathrm{t}$, " $\mathrm{k}$ " is the proportionality constant of the generation of $\mathrm{CH}_{4}$, "a" is the maximum theoretical value that the system will be capable of producing with the degradation of the organic compounds. Time equal to zero is considered $(t=0)$, or the start of methane production, as the initial value that is experimentally detected and $(0)=y_{0}$. Solving the non-linear differential equation using the separation of variables method.

$$
y(t)=\frac{a}{1+e^{-a f-a k t} \text { that can be expressed }} \mid \begin{aligned}
& \text { Sigmoidal Model / Logistic } \\
& \mathrm{y}(\mathrm{t})=\frac{a}{1+b * e^{-c * t}} \\
& \text { Sigmoidal Model / Ratkowsky } \\
& \mathrm{y}(\mathrm{t})=\frac{a}{1+e^{B-c * t}}
\end{aligned}
$$

Table 4 shows the adjustment parameters of the sigmoidal models, and these are associated with the observed phenomenon as follows:

- The coefficient "a" $\left[\mathrm{cm}^{3} \mathrm{CH}_{4} / \mathrm{g}\right.$ VS] estimates: the maximum biomethane production value, considering the total degradation of the biomass, which implies very long times and that the fermentation process is detained when the rate of biogas released becomes insignificant, and corresponds to the reloading of the system with new substrate and inoculum.

- The coefficient "b" [adimensional] is related to: the system starts up $\mathrm{y}(\mathrm{t}=0) \mathrm{y}_{0}$, and the accumulated volume of methane that can be produced by the system "a", b $=\left(a-y_{0}\right) / y_{0}$
- The coefficient "B" [adimensional] is: the natural logarithm of "b"

- The coefficient "c" [minutes ${ }^{-1}$ indicates the speed at which the ability to generate methane reduces and includes all diffusive effects, operational conditions of the experiment and effects surrounding the bacterial consortium. It denotes the rate at which the system consumes the substrate to produce methane, according to the system's generation potential.

Both expressions of the prediction model are equivalent and offer results, with an average certainty of $99 \%$, to describe the volume of $\mathrm{CH}_{4}$ accumulated in the time for the cases analyzed. The Ratkowsky model [47], for the adjustment parameter "B", offers parameters with less dispersion.

Table 5 shows the values for the three cases studied for experiments D2, D3 and D4 on day 38: A) experimental, B) Logístico-Ratkowsky Model prediction C) Generalized Model prediction.

Table 6 shows the values of the adjustment parameters of the Ratkowsky logistical model, considering the normalization of the experimental data and recalculating the values. Based on the average values of the adjustment parameters obtained, a generalized sigmoidal model is proposed to predict the methane production in $\mathrm{AD}$ of the sargassum.

Fig. 2 shows the graphs of the prediction models and experimental information. The generalized predictive model showed the potential of forecasting the behavior of biomethane generation for the different S:I ratios analyzed in this investigation, and it is proposed as a useful forecasting tool for the projection and scaling of AD based sargassum energy harnessing systems.

Recent publications indicate that the mono-digestion of sargassum is unsustainable for energy extraction due to its low efficiency in bioconversion and its unpredictable available volume. Furthermore, the anaerobic co-digestion of sargassum and other organic waste has been identified, as a technology that improves biomethane production, favors its energy harnessing, and presents positive synergy in the degradation of the co-substrates $[22,23]$. The need to dispose of this biomass and wastewater treatment sludge on the Caribbean coast, provides the opportunity for its energy harnessing via AD. Furthermore, according to Głowacka et al. [48] biogas plants can provide subproducts like $\mathrm{CO}_{2}$ for the cultivation of green algae,

\begin{tabular}{|c|c|c|c|c|c|c|}
\hline \multicolumn{7}{|c|}{$\begin{array}{l}\text { Sigmoidal Model / Logistic: } y=a /(1+b * \exp (-c * t)) \\
\text { Sigmoidal Model / Ratkowsky: } y=a /(1+\exp (B-c * t))\end{array}$} \\
\hline \multirow{2}{*}{ Experiment } & \multicolumn{4}{|c|}{ Model parameters } & \multirow{2}{*}{ Correlation Coefficient } & \multirow{2}{*}{ Standard Error } \\
\hline & a & $\mathrm{b}$ & $B=\ln b$ & $\mathrm{c}$ & & \\
\hline D2 & 350.71 & 20.27 & 3.0092 & 0.17 & 0.9968 & 10.46 \\
\hline D3 & 312.37 & 28.14 & 3.3373 & 0.17 & 0.9943 & 12.64 \\
\hline D4 & 209.98 & 55.22 & 4.0114 & 0.16 & 0.9972 & 4.99 \\
\hline
\end{tabular}

Table 4. Adjustment parameters of the Sigmoidal Model. 
Table 5. Accumulated experimental, Modeled Methane Volume and Generalized Model for the three scenarios.

\begin{tabular}{|c|c|c|c|c|c|c|c|c|c|}
\hline \multirow{3}{*}{$\begin{array}{l}\text { Time } \\
\text { [days] }\end{array}$} & \multicolumn{9}{|c|}{ Accumulated methane volume $\left[\mathrm{cm}^{3} \mathrm{CH}_{4} / \mathrm{g} \mathrm{SV}\right]$} \\
\hline & \multicolumn{3}{|c|}{ Experiment } & \multicolumn{3}{|c|}{$\begin{array}{l}\text { Prediction models: } \\
\text { Logistic y Ratkowsky }\end{array}$} & \multicolumn{3}{|c|}{$\begin{array}{c}\text { Prediction: } \\
\text { Generalized model }\end{array}$} \\
\hline & D2 & D3 & D4 & D2 & D3 & D4 & D2 & D3 & D4 \\
\hline 0 & & & & 16 & 11 & 4 & 11 & 10 & 6 \\
\hline 1 & 17 & 2 & 2 & 19 & 13 & 4 & 13 & 12 & 7 \\
\hline 2 & 17 & 4 & 4 & 23 & 15 & 5 & 15 & 14 & 8 \\
\hline 3 & 18 & 4 & 4 & 27 & 18 & 6 & 18 & 16 & 9 \\
\hline 5 & 25 & 8 & 5 & 37 & 24 & 8 & 25 & 23 & 13 \\
\hline 7 & 38 & 16 & 12 & 50 & 34 & 11 & 34 & 31 & 18 \\
\hline 9 & 69 & 50 & 26 & 67 & 46 & 14 & 46 & 42 & 24 \\
\hline 12 & 103 & 78 & 30 & 100 & 70 & 22 & 70 & 64 & 37 \\
\hline 14 & 127 & 93 & 31 & 126 & 90 & 29 & 91 & 83 & 48 \\
\hline 15 & 149 & 105 & 32 & 140 & 102 & 33 & 103 & 94 & 54 \\
\hline 17 & 181 & 140 & 37 & 170 & 127 & 43 & 129 & 118 & 68 \\
\hline 19 & 212 & 166 & 46 & 201 & 154 & 55 & 158 & 145 & 83 \\
\hline 21 & 234 & 187 & 70 & 230 & 181 & 68 & 189 & 173 & 99 \\
\hline 23 & 245 & 204 & 86 & 255 & 207 & 83 & 219 & 200 & 115 \\
\hline 26 & 270 & 226 & 106 & 287 & 240 & 108 & 260 & 238 & 137 \\
\hline 28 & 284 & 238 & 124 & 303 & 257 & 124 & 283 & 259 & 149 \\
\hline 31 & 320 & 264 & 152 & 321 & 277 & 146 & 310 & 284 & 163 \\
\hline 34 & 344 & 294 & 167 & 332 & 291 & 165 & 330 & 302 & 174 \\
\hline 36 & 344 & 303 & 171 & 338 & 297 & 175 & 339 & 310 & 178 \\
\hline 38 & 348 & 319 & 183 & 341 & 301 & 183 & 346 & 316 & 182 \\
\hline
\end{tabular}

which at the same time can be used as a raw material in the AD process.

Studies agree that the success of the marine algae fuel industry depends on the energy balance of the processes, and so evaluations are required that along with identifying the viability of the implementation, also enable the commercialization of the biofuels generated $[22,33]$. It is important that these evaluations are carried out from a life-cycle based perspective. Furthermore, the simultaneous production of bioproducts and biofuels from sargassum enables this seaweed to be integrated into a circular economy, to comply with emerging economic models and promote it as a source of new products [11].

\section{Conclusions and Recommendations}

Based on the ultimate analysis, proximate analysis and BMP experimentation, the maximum theoretical

Table 6. Adjustment parameters for the Ratkowsky and Generalized Models.

\begin{tabular}{|c|c|c|c|c|c|}
\hline \multicolumn{7}{|c|}{ Sigmoidal Model / Ratkowsky: $\mathrm{y}=\mathrm{a} /(1+\exp (\mathrm{B}-\mathrm{c} * \mathrm{t}))$} \\
\hline \multirow{2}{*}{ Experiment } & \multicolumn{3}{|c|}{ Model parameters } & \multirow{2}{*}{ Correlation Coefficient } & Standard Error \\
\cline { 2 - 6 } & $\mathrm{a}$ & $\mathrm{B}=\ln \mathrm{b}$ & $\mathrm{c}$ & 0.9968 & 0.03 \\
\hline D2 & 1.0074 & 3.0117 & 0.17 & 0.9943 & 0.04 \\
\hline D3 & 0.9779 & 3.3437 & 0.17 & 0.9972 & 0.03 \\
\hline D4 & 1.1471 & 4.0226 & 0.16 & 0.9961 & 0.03 \\
\hline Gral Model & 1.0441 & 3.4593 & 0.1684 & & \\
\hline
\end{tabular}




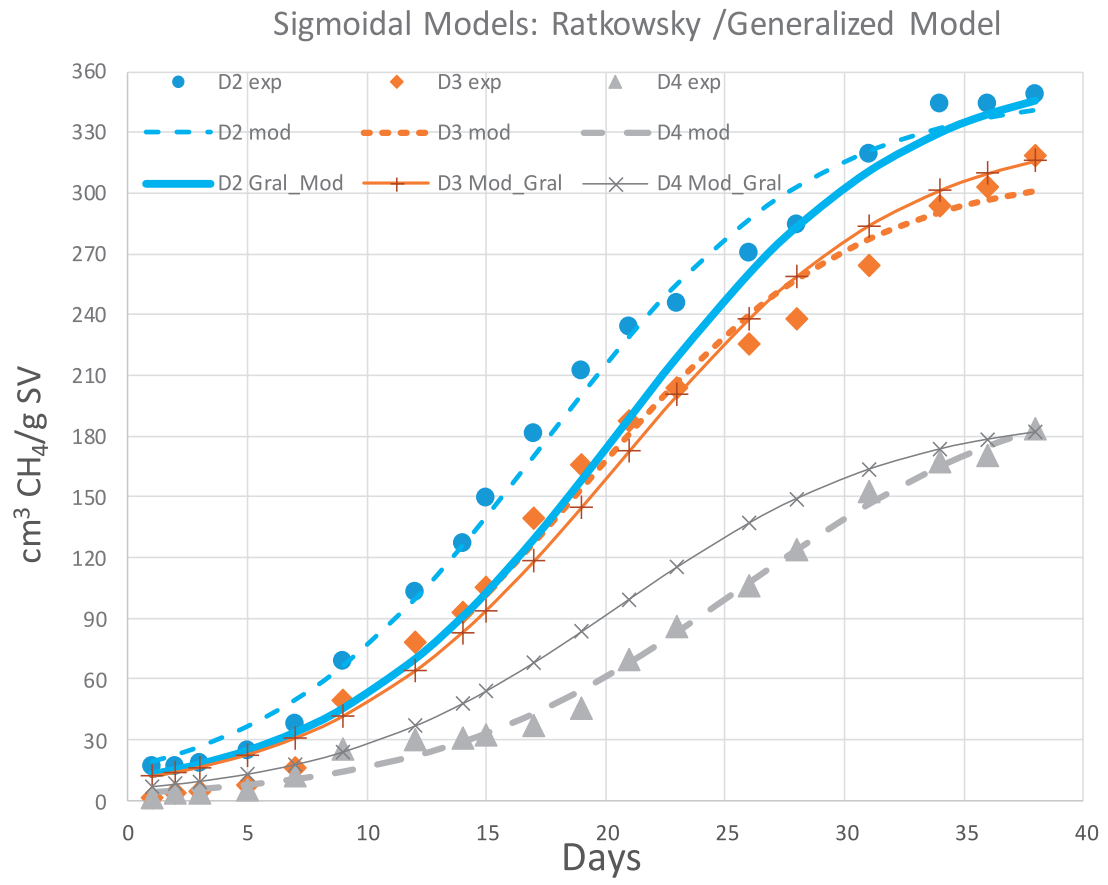

Fig. 2 Experimental data: D2, D3, D4 (D\# exp) and sigmoidal models: Logistic, Ratkowski (D\# mod) and Generalized model (D\# Mod_Gral).

volume of $\mathrm{CH}_{4}$ that sargassum is capable of producing was estimated, and the capacity of its conversion to biogas was experimentally quantified. The theoretical calculation in all cases, predicts that the greater the substrate content the greater the values of SMP and BI $(\mathrm{D} 2<\mathrm{D} 3<\mathrm{D} 4)$. However, the Biochemical Methane Potential (BMP) under laboratory conditions was the opposite $(\mathrm{D} 2>\mathrm{D} 3>\mathrm{D} 4)$. Therefore, the importance of the substrate/inoculum ratio must be considered for scaling. To make its energy harnessing more efficient the use of inoculum adapted and acclimatized to the sargassum's $\mathrm{AD}$ is recommended.

The Logistic and Ratkowsky mathematical model as a tool to describe the phenomenon of biogas production, showed its potential to make the general forecasts that are useful for scaling. The mathematical expression proposed by Ratkowsky is equivalent to the logistics, although it offers greater versatility. Additional BMP tests with different S:I ratios are recommended to generate a more general prediction model, which will enable a more useful prediction model to be obtained.

It is of technical importance for filtration and biogas improvement processes to be integrated into the sargassum's biomethanization systems, to prevent damage due to corrosion of the systems and increase the biogas's caloric value. Furthermore, it is recommended to: a) evaluate the codigestion of sargassum with other available waste like waste water treatment plant sludge and organic domestic waste; b) carry out seasonal studies to identify the parameters of the sargassum; c) evaluate the potential for extracting high value bioproducts like alginic acid, fucoidan, fucoxanthin, laminarina, manitol and some proteins; d) evaluate the production of biomethane from bioactive compound extraction processes; e) study of pyrolysis of digestate for use as a filter medium in the upgrading of biogas.

The presence of $\mathrm{CaCO}_{3}$ and its concentration in the sargassum may be favorable in the production process for cement, when integrated into the clinker as an alternative fuel in the rotary kiln, and to generate a proper disposal method for this type of biomass. The cost of collection, drying and transport of the sargassum to the cement plant should also be evaluated.

The low calorific value determined, considerable presence of ash and detection of aromatic compounds in the sargassum's pyrolysis, limit its application in conventional combustion systems, as its use would generate toxic polluting gases and potential operational issues.

It was discovered that the presence of carbamates and heavy metals in the sargassum's composition did not inhibit fermentation in the experiment. However, the emission of these compounds presents a toxicity risk for the ecosystem, and further specific studies are required to confirm the identity of these compounds in the biomass. The studies proposed are to: a) identify the types with less generalized analysis and their quantification in samples of the sargassum and digestate to determine the viability of its possible application; b) identify the traceability of these components when using digestate as a soil improver.

Also, it is recommended to extend the study by analyzing samples obtained from different areas and 
seasons during a year to validate the performance of the proposed model in the production of biomethane.

The dissemination of information on the use of $\mathrm{AD}$ technology for biogas production and the recovery of sargassum, will enable the generation of alternatives for carrying out the co-processing of this seaweed. The production of renewable fuels will allow, not only the generation of an economic value chain, but also provide proper management of the sargassum, with the aim of reducing the adverse effects of its presence on the ecosystem.

\section{Acknowledgements}

The authors thank the Centro de Investigación en Materiales Avanzados S. C., the technicians Daniel Lardizábal-Gutiérrez, Claudia Patricia Peregrino-Ibarra and Silvia Violeta Miranda-Navarro. As well as the financial support of the Consejo Nacional de Ciencia y Tecnología CONACYT, SENER project 243715 and SEMAR project 305292.

\section{Conflict of Interest}

The authors declare no conflict of interest.

\section{References}

1. WANG M., HU C., BARNES B.B., MITCHUM G., LAPOINTE B., MONTOYA J.P. The great Atlantic Sargassum belt. Science, 365 (6448), 83, 2019.

2. PUTMAN N.F., GONI, G.J., GRAMER L.J., HU C., JOHNS E.M., TRINANES J., WANG M. Simulating transport pathways of pelagic Sargassum from the Equatorial Atlantic into the Caribbean Sea. Progress in oceanography, 165, 205, 2018.

3. GONZÁlEZ M.A., TORRUCO D. Perfiles sociales y económicos en la costa de Quintana Roo: su relación con el turismo de playa. Investigación ambiental, 7 (1), 1, 2015.

4. AZANZA R.J., PÉREZ M.R. Impact of Sargassum influx during 2015 summer on marine turtles of Playa la Barca, Peninsula de Guanahacabibes. Rev Investig Mar, 36 (1), 54, 2016.

5. RODRÍGUEZ-MARTÍNEZ R.E., VAN TUSSENBROEK B., JORDÁN-DAHLGREN E. Afluencia masiva de sargazo pelágico a la costa del Caribe mexicano (20142015). Florecimientos Algales Nocivos en México. Ensenada: CICESE, 352, 2016.

6. MILledGE J., HARVEY P. Golden Tides: Problem or golden opportunity? The valorisation of Sargassum from beach inundations. Journal of Marine Science and Engineering, 4 (3), 60, 2016.

7. RODRÍGUEZ-MARTÍNEZ R.E., MEDINAVALMASEDA A.E., BLANCHON P., MONROYVELÁZQUEZ, L.V., ALMAZÁN-BECERRIL A., DELGADO-PECH B., Vásquez-Yeomans 1., FRANCISCO V., GARCÍA-RIVAS M.C. Faunal mortality associated with massive beaching and decomposition of pelagic Sargassum. Marine Pollution Bulletin, 146, 201, 2019.
8. OVIATT C.A., HUIZENGA K., ROGERS C.S., MILLER W.J. What nutrient sources support anomalous growth and the recent sargassum mass stranding on Caribbean beaches? A review. Marine Pollution Bulletin, 145, 517, 2019.

9. LOUIME C., FORTUNE J., GERVAIS G. Sargassum invasion of coastal environments: a growing concern. Am J Environ Sci, 13 (1), 58, 2017.

10. VAN TUSSENBROEK B.I., ARANA H.A. H., RODRÍGUEZ-MARTÍNEZ R.E., ESPINOZA-AVALOS J., CANIZALES-FLORES H.M., GONZÁLEZ-GODOY C.E., BARBA-SANTOS M.G., VEGA-ZEPEDA A., COLLADO-VIDES L. Severe impacts of brown tides caused by Sargassum spp. on near-shore Caribbean seagrass communities. Marine pollution bulletin, 122 (1-2), 272, 2017.

11. SALDARRIAGA-HERNÁNDEZ S., HERNANDEZVARGAS G., IQBAL H.M., BARCELÓ D., PARRASALDÍVAR R. Bioremediation potential of Sargassum sp. biomass to tackle pollution in coastal ecosystems: Circular economy approach. Science of The Total Environment, 715, 136978. 2020.

12. SANJEEWA K.A., KANG N., AHN G., JEE Y., KIM Y.T., JEON Y.J. Bioactive potentials of sulfated polysaccharides isolated from brown seaweed Sargassum spp in related to human health applications: a review. Food Hydrocolloids, 81, 200, 2018.

13. CASAS M.P., CONDE E., DOMÍNGUEZ H., MOURE A. Ecofriendly extraction of bioactive fractions from Sargassum muticum. Process biochemistry, 79, 166, 2019.

14. ZHANG R., ZHANG X., CHEN Z., TANG Y., MAO J. Composition, isolation, purification and biological activities of Sargassum fusiforme polysaccharides: A review. Carbohydrate polymers, 228, 115381, 2020.

15. JESUMANI V., DU H., PEI P., ZHENG C., CHEONG K.L., HUANG N. Unravelling property of polysaccharides from Sargassum sp. as an anti-wrinkle and skin whitening property. International Journal of Biological Macromolecules, 140, 216, 2019.

16. FERNÁNDEZ F., BOLUDA C.J., OLIVERA J., GUILLERMO L.A., GÓMEZ B., ECHAVARRÍA E., MENDIS GÓMEZ A. Análisis Elemental Prospectivo de la Biomasa algal acumulada en las costas de la República Dominicana durante 2015. Centro Azúcar, 44 (1), 11, 2017.

17. MARQUEZ G.P.B., SANTIAÑEZ W.J.E., TRONO JR G.C., MONTAÑO M.N.E., ARAKI H., TAKEUCHI H., HASEGAWA T. Seaweed biomass of the Philippines: sustainable feedstock for biogas production. Renewable and Sustainable Energy Reviews, 38, 1056, 2014.

18. SOTO M., VAZQUEZ M.A., DE VEGA A., VILARINO J.M., FERNANDEZ G., DE VICENTE M.E.S. Methane potential and anaerobic treatment feasibility of Sargassum muticum. Bioresource technology, 189, 53, 2015.

19. MILLEDGE J.J., HARVEY P.J. Ensilage and anaerobic digestion of Sargassum muticum. Journal of applied phycology, 28 (5), 3021, 2016.

20. NKEMKA V.N., MURTO M. Evaluation of biogas production from seaweed in batch tests and in UASB reactors combined with the removal of heavy metals. Journal of Environmental Management, 91 (7), 1573, 2010.

21. MIRMOHAMADSADEGHI S., KARIMI K., TABATABAEI M., AGHBASHLO M. Biogas production from food wastes: A review on recent developments and future perspectives. Bioresource Technology Reports, 7, $100202,2019$.

22. THOMPSON T.M., YOUNG B., BAROUTIAN S. Pelagic Sargassum for energy and fertiliser production in the 
Caribbean: A case study on Barbados. Renewable and Sustainable Energy Reviews, 118, 109564, 2020.

23. SARATALE R.G., KUMAR G., BANU R., XIA A., PERIYASAMY S., SARATALE G.D. A critical review on anaerobic digestion of microalgae and macroalgae and co-digestion of biomass for enhanced methane generation. Bioresource technology, 262, 319, 2018.

24. ISSAH A.A., KABERA T., KEMAUSUOR F. Biogas optimisation processes and effluent quality: A review. Biomass and Bioenergy, 133, 105449, 2020.

25. RASAPOOR M., YOUNG B., BRAR R., SARMAH A., ZHUANG W.Q., BAROUTIAN S. Recognizing the challenges of anaerobic digestion: Critical steps toward improving biogas generation. Fuel, 261, 116497, 2020.

26. SOTO J.J.S., YEOMANS L.V., PERERA A.A., MONDRAGÓN C.C., VÁZQUEZ J.A.C. Lista de peces marinos del Caribe mexicano. Anales del Instituto de Biología. Serie Zoología, 71 (2), 143, 2000.

27. SUÁREZ A.M., MARTÍNEZ-DARANAS B. La problemática del Sargazo en el caribe. Adaptación basada en Ecosistemas: alternativa para la gestión sostenible de los recursos marinos y costeros del Caribe, 82, 2018.

28. FEDERATION W.E., AMERICAN PUBLIC HEALTH ASSOCIATION. Standard methods for the examination of water and wastewater. American Public Health Association (APHA): Washington, DC, USA. 2005.

29. STANDARD A.S.T.M. E1131-08 Standard test method for compositional analysis by thermogravimetry. ASTM International, West Conshohocken: PA, 2008.

30. MEXICANA N. NMX-AA-051-SCFI-2001. Determinación de metales por absorción atómica en aguas naturales, potables, residuales y residuales tratadas, 2001.

31. WELLINGER A., MURPHY J. D., BAXTER, D. The biogas handbook: science, production and applications. Elsevier, 2013.

32. KOCH K., LIPPERT T., DREWES J.E. The role of inoculum's origin on the methane yield of different substrates in biochemical methane potential (BMP) tests. Bioresource technology, 243, 457, 2017.

33. TEDESCO S., DANIELS S. Optimisation of biogas generation from brown seaweed residues: Compositional and geographical parameters affecting the viability of a biorefinery concept. Applied energy, 228, 712, 2018.

34. LEE J., HONG J., JEONG S., CHANDRAN K., PARK K. Y. Interactions between substrate characteristics and microbial communities on biogas production yield and rate. Bioresource Technology, 303, 122934. 2020.

35. FILER J., DING H. H., CHANG S. Biochemical methane potential (BMP) assay method for anaerobic digestion research. Water, 11 (5), 921, 2019.

36. MOSET V., AL-ZOHAIRI N., MØLLER H.B. The impact of inoculum source, inoculum to substrate ratio and sample preservation on methane potential from different substrates. Biomass and Bioenergy, 83, 474, 2015.
37. VILAR E.G., O'SULLIVAN M.G., KERRY J.P., KILCAWLEY K.N. Volatile compounds of six species of edible seaweed: A review. Algal Research, 45, 10174, 2020.

38. OLIVEIRA T.M., RIBEIRO F.W., SOUSA C.P., SALAZAR-BANDA G.R., DE LIMA-NETO P., CORREIA A.N., MORAIS S. Current overview and perspectives on carbon-based (bio) sensors for carbamate pesticides electroanalysis. TrAC Trends in Analytical Chemistry, 124, 115779, 2019.

39. MA J., LU N., QIN W., XU R., WANG Y., CHEN X.. Differential responses of eight cyanobacterial and green algal species, to carbamate insecticides. Ecotoxicology and Environmental safety, 63 (2), 268, 2006.

40. MEXICANA N.O. NOM-001-SEMARNAT-1996. Establece los límites máximos permisibles de contaminantes en las descargas de aguas residuales en aguas y bienes nacionales. Diario Oficial de la Federación. México, DF. 1997.

41. STRÖMBERG S., NISTOR M., LIU J. Towards eliminating systematic errors caused by the experimental conditions in Biochemical Methane Potential (BMP) tests. Waste management, 34 (11), 1939, 2014.

42. LAKOTA M., VINDI P. Parametric and Nonparametric Approaches for Detecting the most Important Factors in Biogas Production. Polish Journal of Environmental Studies, 28 (1), 291, 2019.

43. LI Y., WANG Y., YU Z., LU J., LI D., WANG G., LI Y., WU Y., LI S., XU F., LI G., GONG X. Effect of inoculum and substrate/inoculum ratio on the performance and methanogenic archaeal community structure in solid state anaerobic co-digestion of tomato residues with dairy manure and corn stover. Waste Management, 81, 117, 2018.

44. TABASSUM M.R., WALL D.M., MURPHY J.D. Biogas production generated through continuous digestion of natural and cultivated seaweeds with dairy slurry. Bioresource technology, 219, 228, 2016.

45. SUN Q., LI H., YAN J., LIU L., YU Z., YU X. Selection of appropriate biogas upgrading technology-a review of biogas cleaning, upgrading and utilisation. Renewable and Sustainable Energy Reviews, 51, 521, 2015.

46. KWAŚNY J., BALCERZAK W. Sorbents Used for Biogas Desulfurization in the Adsorption Process. Polish Journal of Environmental Studies, 25 (1), 37, 2016.

47. RATKOWSKY D.A., LOWRY R.K., MCMEEKIN T.A., STOKES A.N., CHANDLER R. Model for bacterial culture growth rate throughout the entire biokinetic temperature range. Journal of bacteriology, 154 (3), 1222, 1983.

48. GŁOWACKA N., GADUŠ J., SLOBODNÍK J. Anaerobic Digestion of Microalgal Biomass Acutodesmus dimorphus (Turpin) P. Tsarenko as a Substrate for Biogas Production. Polish Journal of Environmental Studies, 27 (4), 1497, 2018. 